\title{
Fungicide Application Timing Essential for the Management of Leaf Spot and Fruit Rot on Pomegranate (Punica granatum L.) in Florida
}

\author{
K. V. Xavier, A. N. KC, and G. E. Vallad ${ }^{\dagger}$ \\ University of Florida, Gulf Coast Research and Education Center, Wimauma, FL 33598, U.S.A.
}

\begin{abstract}
Pomegranate (Punica granatum L.) has emerged as an alternative fruit crop for growers dealing with devastating threats to citrus and avocado in the southeastern United States. However, foliar and fruit diseases are major constraints to commercial pomegranate production. Replicated field trials were performed in 2015 at three separate sites in Florida (Dover, Plant City, and Parrish) to evaluate Merivon (pyraclostrobin and fluxapyroxad), Luna Experience (fluopyram + tebuconazole), and a rotational program consisting of these two fungicides as well as Penncozeb 75DF (mancozeb) for the management of leaf spot and fruit rot of pomegranate. The fungicide programs were evaluated on the varieties Vietnam in Dover, FL; Angel Red in Plant City, FL; as well as Christina, Azadi, Vikusnyi, Alsirinnar,

$54.2 \%$ in Parrish. Based on area under the disease progress curve, all treatments that included at least one at bloom application significantly reduced disease levels compared with postbloom treatments and the nontreated control across all trial sites. Based on fruit rot incidence, Luna Experience and Merivon, when applied twice at bloom in the beginning of the season, reduced disease by 66.6 and $88.4 \%$, respectively, in comparison with the nontreated control in Plant City. A rotational program further reduced disease by at least $97 \%$ at the end of the season in Parrish. The proper timing of fungicide application and rotation with different modes of action provided a feasible disease management option for pomegranate growers in the Southeast United States.
\end{abstract} Sakerdze, and Wonderful in Parrish, FL. Mean leaf spot severity varied across sites at the end of each trial in August, with values ranging from 4.5 to $62.5 \%$ in Plant City, 7.5 to $45.8 \%$ in Dover, and 4.5 to
Keywords: chemical, cultivar/resistance, disease management, fruit, pomegranate, southeast U.S., tree fruits
Pomegranate (Punica granatum L.) is a subtropical tree fruit that has been cultivated in some parts of North America, Asia, and Europe (Jain and Desai 2018; Quiroz 2009). In the United States, California is the main producer, with 12,545 planted hectares (NASS 2012). Recently, pomegranate has emerged as an alternative fruit crop in the southeastern United States for growers dealing with devastating threats to citrus and avocado orchards from invasive pests and diseases (Halbert and Manjunath 2004; Mayfield et al. 2008; Spreen and Baldwin 2013). However, pomegranate trees, like citrus and avocado, are prone to several diseases that can lead to economic losses.

The most common pomegranate disease symptoms worldwide include foliar leaf spot, fruit rot, canker, shoot blight, and dieback (Chen et al. 2014; Hebert and Clayton 1963; Johanningsmeier and

Current address of A. N. KC: Oregon State University, Southern Oregon Research and Extension Center, 569 Hanley Rd, Central Point, OR 97502, U.S.A.

${ }^{\dagger}$ Corresponding author: G. E. Vallad; gvallad@ufl.edu

Funding: Funding for this project was made possible by the United States Department of Agriculture (USDA) Agricultural Marketing Service (AMS) and the Florida Department of Agriculture and Consumer Services (FDACS) through USDA-AMS-SCBGP-2012 award 92288 and USDA-AMSSCBGP-2015 award 22899, with administrative support from the Florida Specialty Crop Foundation (FSCF) and input from the Florida Pomegranate Association (FPA)

Contents presented in this article are solely the responsibility of the authors and do not necessarily represent the official views of the USDA, FDACS, FSCF, or FPA.

*The $\boldsymbol{e}$-Xtra logo stands for "electronic extra" and indicates that three supplementary tables are published online.

The author(s) declare no conflict of interest.

Accepted for publication 31 January 2020.

(C) 2020 The American Phytopathological Society
Harris 2011; Munhuweyi et al. 2016; Palou et al. 2013; Sharma and Tegta 2011; Úrbez-Torres et al. 2016). For example, Neofusicoccum parvum is a fungal pathogen which causes canker, shoot blight, and dieback (KC and Vallad 2016a; Palavouzis et al. 2015), whereas Colletotrichum spp. and Pseudocercospora punicae are the leading cause of fungal blight and leaf spot diseases on pomegranate (Benagi et al. 2011; Jadhav and Sharma 2009; Munhuweyi et al. 2016). Common fruit rot pathogens include Pilidiella granati, Colletotrichum spp., Penicillium spp., Alternaria alternata, Aspergillus niger, and Botrytis cinerea (Chen et al. 2014; KC and Vallad 2016b; Thomidis 2014). Fruit rots are of particular importance because the symptomatic fruit become completely unmarketable and unsuitable for juice production (Munhuweyi et al. 2016).

Pomegranate is a relatively new commercial crop in the southeastern United States; thus, there is limited information in the literature about the diseases occurring in the region. Disease surveys conducted on pomegranate orchards from 2014 to 2016 in the southeastern United States revealed that numerous fungal species were associated with pomegranate diseases, including several species of Colletotrichum (Xavier et al. 2019b), Dwiroopa punicae (Xavier et al. 2019a), N. parvum (KC and Vallad 2016a), P. granati (KC and Vallad 2016b), and several others (KC and Vallad 2015). All of these fungal species were pathogenic on both leaves and fruit, causing a range of leaf spot and fruit decay symptoms (KC and Vallad 2015, 2016a,b). The presence of these fungal pathogens highlights the need for a strategy to manage the pests in these new growing areas.

The main strategy recommended for the management of fruit rot in the major pomegranate production areas around the world is the use of chemical control (Munhuweyi et al. 2016; Thomidis 2014). Fungicides are typically applied postharvest to control decay caused by various pathogens that can develop even under low storage temperatures of 5 to $8^{\circ} \mathrm{C}$ and relative humidity of $95 \%$ (D'Aquino et al. 2010; Tedford et al. 2005). There are only a few studies in the literature reporting the preharvest use of fungicides on pomegranate. A reduction in the incidence of pomegranate fruit rot of more than $90 \%$ was observed in a program that included propiconazole or a mixture of carbendazim and mancozeb (Nargund et al. 2012). Difenoconazole and propiconazole have also been reported as highly effective in controlling preharvest anthracnose and fruit spot of 
pomegranate (Patel 2009; Prashanth et al. 2008). Currently, there are no chemical fungicides labeled for preharvest disease control on pomegranate in the United States. Because no management strategies for disease control in the southeastern United States are found in literature, growers have relied mostly on the use of cultural practices to reduce disease in their orchards. The investigation into chemical control of foliar diseases common in this region can aid growers in managing diseases on pomegranate.

It has been well documented that fungal pathogens can remain quiescent on various fruit crops, including mango, blueberry, grape, and strawberry (Arauz 2000; Chung et al. 2003; MacKenzie et al. 2007; Peres et al. 2008; Polashock et al. 2005; Sergeeva et al. 2008). B. cinerea and Colletotrichum spp. are examples of pathogens able to infect floral tissues and immature fruit, including pomegranate, and remain latent during fruit development, only progressing into fruit rot at harvest or even postharvest (Arauz 2000; Jeffries et al. 1990; Tedford et al. 2005; Verma et al. 2006; Wharton and Diéguez Uribeondo 2004). One of the management strategies recommended for the control of fruit rots in several fruit crops is at bloom fungicide applications (Arauz 2000; Peres et al. 2002; Thomas-Sharma and Scherm 2017), which is effective in other growing areas such as India (Nargund et al. 2012) but has not been investigated in the southeastern United States.
Epidemiological information for many pomegranate diseases is still lacking, which limits efforts in the southeastern United States to develop specific management recommendations. Because bloom infections play an important role in the management of many fruit crops, our first objective was to determine the frequency of pathogen recovery from nonsymptomatic flowers. The second objective was to compare differences in efficacy of Merivon versus Luna Experience; as well as to compare each one with a rotational program with a contact fungicide, Penncozeb 75DF. Our third objective was to evaluate the importance of at bloom fungicide applications for the control of foliar and fruit diseases of pomegranate.

\section{Materials and Methods}

Fungal isolation from flower buds. Isolations were performed from 595 flower buds collected from pomegranate trees from three orchards in Florida and two orchards in Georgia in spring 2016 from the first week of April to the first week of May. Asymptomatic flower buds were randomly collected at different stages of development across multiple trees at each orchard. The buds were surface disinfected for $2 \mathrm{~min}$ in a $1 \%$ solution of sodium hypochlorite $(\mathrm{NaOCl})$, rinsed three times in sterile distilled water, and air dried under aseptic conditions. Flower buds were then cut in half with a sterile scalpel, with the cut side of each half placed on V8 agar (15.0 g of agar,

Table 1. Details of fungicide treatments, rates, and application dates for replicated field trials conducted at pomegranate production sites in Dover, Parrish, and Plant City, FL

\begin{tabular}{|c|c|c|}
\hline Trial, code & Treatment & Rate (application date) $)^{x}$ \\
\hline \multicolumn{3}{|c|}{ Luna Experience } \\
\hline L1 & Seasonal, beginning at bloom & $101.7 \mathrm{ml} / \mathrm{ha}(1,4,7,9)$ \\
\hline $\mathrm{L} 2$ & Two at bloom and two postbloom & $101.7 \mathrm{ml} / \mathrm{ha}(1,2,9,10)$ \\
\hline L3 & Two at bloom & $203.5 \mathrm{ml} / \mathrm{ha}(1,2)$ \\
\hline L4 & One at bloom and two postbloom & $203.5(1)$ and 17.9 liters/ha $(9,10)$ \\
\hline L5 & Seasonal, postbloom & $101.7 \mathrm{ml} / \mathrm{ha}(5,7,8,10)$ \\
\hline L6 & Nontreated control & $\ldots$ \\
\hline \multicolumn{3}{|l|}{ Merivon } \\
\hline M1 & Seasonal, beginning at bloom & $83.8 \mathrm{ml} / \mathrm{ha}(1,4,7,9)$ \\
\hline M2 & Two at bloom and two postbloom ${ }^{y}$ & $83.8 \mathrm{ml} / \mathrm{ha}(1,2,9,10)$ \\
\hline M3 & Two at bloom, low rate & $83.8 \mathrm{ml} / \mathrm{ha}(1,2)$ \\
\hline M4 & Two at bloom, high rate & $167.5 \mathrm{ml} / \mathrm{ha}(1,2)$ \\
\hline M5 & Seasonal postbloom, low rate & $83.8 \mathrm{ml} / \mathrm{ha}(9,10)$ \\
\hline M6 & Seasonal, postbloom high rate & $167.5 \mathrm{ml} / \mathrm{ha}(9,10)$ \\
\hline M7 & Nontreated control & $\ldots$ \\
\hline \multicolumn{3}{|l|}{ Rotational $^{\mathrm{z}}$} \\
\hline \multirow[t]{4}{*}{ MLP1 } & One rotation at bloom and one postbloom & \\
\hline & Merivon & 83.8 ml/ha $(1,7)$ \\
\hline & Luna Experience & $203.5 \mathrm{ml} / \mathrm{ha}(3,10)$ \\
\hline & Penncozeb 75DF & $1.1 \mathrm{~kg} / \mathrm{ha}(5,8)$ \\
\hline \multirow[t]{4}{*}{ MLP2 } & One rotation at bloom and one postbloom & \\
\hline & Merivon & $83.8 \mathrm{ml} / \mathrm{ha}(1,8)$ \\
\hline & Luna Experience & $101.7 \mathrm{ml} / \mathrm{ha}(2,9)$ \\
\hline & Penncozeb 75DF & $0.7 \mathrm{~kg} / \mathrm{ha}(3,10)$ \\
\hline \multirow[t]{4}{*}{ MLP3 } & Two rotations at bloom & \\
\hline & Merivon & $83.8 \mathrm{ml} / \mathrm{ha}(1,4)$ \\
\hline & Luna Experience & $203.5 \mathrm{ml} / \mathrm{ha}(2,5)$ \\
\hline & Penncozeb 75DF & $1.1 \mathrm{~kg} / \mathrm{ha}(3,6)$ \\
\hline \multirow[t]{4}{*}{ MLP4 } & One rotation at bloom and postbloom & \\
\hline & Merivon & $83.8 \mathrm{ml} / \mathrm{ha}(1,7)$ \\
\hline & Luna Experience & $203.5 \mathrm{ml} / \mathrm{ha}(2,10)$ \\
\hline & Penncozeb 75DF & $0.7 \mathrm{~kg} / \mathrm{ha}(3,8)$ \\
\hline \multirow[t]{4}{*}{ MLP5 } & Two postbloom rotations & \\
\hline & Merivon & $83.8 \mathrm{ml} / \mathrm{ha}(5,8)$ \\
\hline & Luna Experience & $101.7 \mathrm{ml} / \mathrm{ha}(6,10)$ \\
\hline & Penncozeb 75DF & $0.7 \mathrm{~kg} / \mathrm{ha}(7,10)$ \\
\hline MLP6 & Nontreated control & $\ldots$ \\
\hline
\end{tabular}

${ }^{x}$ Fungicide treatments were applied on 22 March, 5 April, 19 April, 3 May, 17 May, 31 May, 14 June, 12 July, 26 July, and 9 August (corresponding with applications 1 to 10) in Plant City and Dover and 24 March, 7 April, 21 April, 5 May, 19 May, 2 June, 16 June, 14 July, 28 July, and 11 August (corresponding with applications 1 to 10) in Parrish.

y Plant City and Dover only.

${ }^{\mathrm{z}}$ Rotational trial $=$ Luna Experience + Merivon + Penncozeb 75DF. 
$200 \mathrm{ml}$ of $\mathrm{V} 8$ juice, and $2.0 \mathrm{~g}$ of $\mathrm{CaCO}_{3}$ per liter) amended with $0.01 \mathrm{~g}$ of rifampicin and $0.25 \mathrm{~g}$ of ampicillin per liter. Cultures were incubated at $25^{\circ} \mathrm{C}$ under continuous light for 3 to 5 days, and singlespore cultures were obtained from colonies emerging from the infected tissues. Most fungal species were identified based on molecular analysis of the internal transcribed spacer (ITS) region, using ITS1 and ITS4 primers (White et al. 1990), as well as morphological characteristics using taxonomic keys for fungal identification (Hanlin 1990; 1998; KC and Vallad 2015, 2016a,b). Isolates of Alternaria, Aspergillus, and Pestalotiopsis were identified to genus level based on morphological characteristics and by sequencing of the ITS region (KC and Vallad 2015), whereas isolates of Colletotrichum have been identified as belonging to several species (Xavier et al. 2019b). Finally, D. punicae was reported for the first time as a plant pathogen (Xavier et al. 2019a).

Fungicide applications. Trials were established in 2016 at three grower sites in Florida and trees were first sprayed when they had at least $20 \%$ bud break. Evaluated fungicides included Merivon SC (BASF, Research Triangle Park, NC, U.S.A.), containing pyraclostrobin $(21.26 \%)+$ fluxapyroxad (21.26\%); Luna Experience SC (Bayer CropScience, Research Triangle Park, NC, U.S.A.), containing fluopyram (17.6\%) + tebuconazole (17.6\%); and Penncozeb 75DF (United Phosphorus, Inc., King of Prussia, PA, U.S.A.), containing mancozeb $(75 \%)$ (Table 1). Product rate was based on the manufacturer's recommendations for other tree fruit crops, as part of our effort to expand pesticide registration to include pomegranate (Table 1). Luna Experience and Merivon were evaluated individually and as a rotational program that included Penncozeb 75DF comparing the effect of pre- and postbloom application times on disease development during the season. Timing applications of Luna Experience are abbreviated as L1 $=$ four seasonal, beginning at bloom; $\mathrm{L} 2=$ two at bloom and two postbloom; L3 = two at bloom; L4 = one at bloom and two postbloom; L5 = four postbloom; and L6 = nontreated control (Table 1). Timing applications of Merivon are abbreviated as M1 = four seasonal, beginning at bloom; M2 = two at bloom and two postbloom (only performed in Plant City and Dover); M3 = two at bloom, low rate; M4 = two at bloom, high rate; $\mathrm{M} 5$ = two postbloom, low rate; $\mathrm{M} 6$ = two postbloom, high rate; and M7 = nontreated control (Table 1). Timing applications for the rotational program are abbreviated as MLP1 $=$ one rotation at bloom and one postbloom; MLP2 = one rotation at bloom and one postbloom; MLP3 = two rotations at bloom; MLP4 = one rotation at bloom at the beginning of the season and one postbloom at the end of season; MLP5 = two postbloom rotations; and MLP6 = nontreated control (Table 1).

Fungicide treatments were applied with a $\mathrm{CO}_{2}$ backpack sprayer calibrated to deliver 46 liters/ha at $275.8 \mathrm{kPa}$. The applications were made at 14-day intervals at each site starting on 22 March in Plant City and Dover and 24 March in Parrish. All trees used in this trial were planted with a row spacing of $5.8 \mathrm{~m}$ and tree spacing of $2.7 \mathrm{~m}$. Varieties used in Plant City and Dover included 6-year-old Angel Red and 7year-old Vietnam trees, respectively. In both Plant City and Dover, there were three replications per treatment, consisting of a single tree per replicate. In Parrish, there was an inadequate number of trees of the same variety for a complete trial to directly compare the fungicides; thus, timing and frequency of application for each fungicide were evaluated on two separate varieties. Therefore, the trial in Parrish consisted of two varieties of 6-year-old trees for each treatment: Azadi and Vikusnyi (Luna Experience), Christina and Wonderful (Merivon), and Alsirinnar and Sakerdze (rotation with Merivon, Luna Experience, and Penncozeb 75DF), with three single-tree replications per treatment in each variety for a total of six trees per treatment.

In Dover and Plant City, a nested design was used with application timing (treatments) randomized as subplots nested within each fungicide program. In Parrish, due to the limited number of trees per variety, each treatment (fungicide program $\times$ application timing) was randomized as subplots nested within each pomegranate variety. Trees in each location were naturally infected.

Leaf disease data collection and statistical analysis. Leaf spot severity, rated as the proportion of canopy affected on individual trees using the Horsfall-Barratt scale (Horsfall and Barratt 1945), was assessed every 2 weeks starting on 7 April in Parrish and 5 April in Plant City and Dover. The midpoint percentage of the HorsfallBarratt rating was applied for data analysis (Horsfall and Barratt 1945). The area under the disease progress curve (AUDPC) was calculated using the formula $\Sigma\left\{\left[\left(x_{i}+x_{i-1}\right) / 2\right]\left(t_{i}-t_{i-1}\right)\right\}$, where $x_{i}$ is the midpoint percentage of the Horsfall-Barratt rating at each evaluation time and $\left(t_{i}-t_{i-1}\right)$ is the time between evaluations; the values represent estimates of least square means for treatments (Horsfall and Barratt 1945).

The effect of treatments (including fungicide and nontreated control) or timing of fungicide application on AUDPC was conducted separately for each site using a generalized linear mixed-model analysis (PROC GLIMMIX, SAS version 9.4; SAS Institute, Cary, NC, U.S.A.) with replication as a random effect. In Dover and Plant City, when the effect of fungicide on AUDPC was found to be significant, differences among fungicide application timings were compared. In Parrish, when plant variety on AUDPC was found to be significant, differences among fungicide application timings for each plant variety were compared. For all three sites, differences among fungicide application timings were compared using Fisher's protected least significant difference method for mean separation at the $95.0 \%$ level of confidence.

Yield data and diseased fruit. The incidence of diseased fruit was assessed on 2 June and 8 September in Parrish and 31 May and 24 August in Plant City and Dover. The number of infected fruit (showing fruit spot symptoms or brown rot at the calyx) per tree was counted. Mature fruit were harvested on 7 and 8 September in Plant City and Parrish, respectively. Harvested fruit were considered marketable when less than $5 \%$ of the fruit surface was visibly marred. The incidence of diseased fruit was calculated as a percentage of the total number of fruit per tree and subjected to a generalized linear mixed-model analysis (as described previously). Fruit were not harvested in Dover, because Vietnam is an evergreen variety that flowers and sets fruit throughout the year and showed no clear response to fungicide application timing on fruit disease incidence.

\section{Results}

Fungal isolation from flower buds. Among 595 flower buds tested, only $19.5 \%$ were free of any internal fungal colonization based on recovery on V8 media (Table 2). Mixed cultures of two or more isolates were recovered from at least $75 \%$ of the samples that were colonized by fungi. Pure cultures of individual fungal species were obtained. Of the recovered fungal isolates identified based on ITS region, only the pathogenic species identified on pomegranate from previous studies were used for data analysis (Ezra et al. 2015; KC and Vallad 2015, 2016a,b; Luo et al. 2017; Michailides and Morgan 2016; Morgan and Michailides 2012; Philip 1979).

Overall, more than $30 \%$ of the recovered fungal isolates belonged to the species D. punicae (Table 2). The same pathogen was recovered from 15.4, 17.4, 32.5, and $50.0 \%$ of flower buds collected at Live Oak $(n=26)$, Haines City $(n=235)$, Zolfo Springs $(n=126)$ in Florida and in Georgia $(n=208)$, respectively. The second most

Table 2. Percent recovery of fungal species from surface-sterilized pomegranate flower buds $(n=595)$ collected in Florida and Georgia in 2016

\begin{tabular}{lrrrrrrrr}
\hline & & \multicolumn{6}{c}{ Fungal species recovery $(\%)^{\mathbf{z}}$} \\
\cline { 3 - 9 } Location & Totaly & Alt & Dwi & Asp & Bot & Col & Pes & None \\
\hline Alma, GA & 108 & 0.9 & 48.1 & 0.0 & 41.7 & 9.3 & 0.0 & 0.0 \\
Tifton, GA & 100 & 2.0 & 51.0 & 0.0 & 44.0 & 0.0 & 0.0 & 3.0 \\
Live Oak, FL & 26 & 0.0 & 15.4 & 3.8 & 7.7 & 30.8 & 0.0 & 42.3 \\
Haines City, FL & 235 & 25.1 & 17.4 & 6.4 & 0.9 & 6.4 & 26.0 & 17.9 \\
Zolfo Spring, FL & 126 & 9.5 & 32.5 & 1.6 & 0.0 & 8.7 & 0.0 & 47.6 \\
$\begin{array}{l}\text { Total flower buds } \\
\text { tested }\end{array}$ & 595 & 12.4 & 31.8 & 3.0 & 15.6 & 7.4 & 10.3 & 19.5 \\
\hline
\end{tabular}

y Total number of buds in each location.

${ }^{\mathrm{z}}$ Alt $=$ Alternaria sp., Dwi $=$ Dwiroopa punicae, Asp $=$ Aspergillus $\mathrm{sp} .$, Bot $=$ Botryosphaeriacea (including Neofusicoccum parvum and Lasiodiplodia spp.), Col $=$ Colletotrichum spp., and Pes $=$ Pestalotiopsis sp. 
frequently recovered group of pathogens was from the Botryosphaeriaceae family ( $N$. parvum and Lasiodiplodia spp.), with more than $40 \%$ of the isolates recovered from flower buds collected in Georgia $(n=208)$ (Table 2). In Florida, isolates were recovered from around 8 and $1 \%$ of flower buds from Live Oak and Haines City, respectively, whereas no isolates were recovered from flower buds collected in Zolfo Springs. In Georgia, more than $40 \%$ of the isolates recovered were from the Botryosphaeriaceae family $(n=208)$ (Table 2$)$. Alternaria spp. made up the third most frequently recovered group, representing $12.4 \%$ of isolates, with the highest percentage recovered from Haines City. Pestalotiopsis spp. were recovered from almost $11 \%$ of the total flower buds; however, this fungal isolate was not observed among flower buds collected from Georgia pomegranate orchards (Table 2). Colletotrichum spp. were recovered from $7.4 \%$ of flower buds, on average, from all collection sites in Florida and Georgia. However, the frequency of recovery for Colletotrichum spp. varied among the different sites, ranging from $0 \%$ in Tifton $(n=100)$ to $9.3 \%$ flower buds in Alma $(n=108)$. In Florida, the recovery of Colletotrichum spp. was higher on average and varied from $6.4 \%$ of flower buds in Haines City $(n=235)$ to $30.8 \%$ of flower buds collected in Live Oak $(n=26)$. The lowest recovery consisted of Aspergillus spp., representing only $3 \%$ of the total recovered isolates, with all isolates recovered from Florida (Table 2).

Fungicide efficacy on foliar diseases. Pomegranate trees were sprayed with Merivon, Luna Experience, and a rotational program consisting of these two fungicides and Penncozeb 75DF. Disease evaluations began in April during bloom, because natural inoculum provided adequate disease pressure at all three locations. Significant differences in disease severity among treatments in comparison with the nontreated control were detected in April, May, and June in Dover (Supplementary Table S1), Plant City (Supplementary Table S2), and Parrish, respectively. Average disease severity ranged from 4.5 to $62.5 \%$ in Plant City, 7.5 to $45.8 \%$ in Dover, and 4.5 to $54.2 \%$ in Parrish, based on the final rating in late August.

The efficacy of Merivon, Luna Experience, and the rotational program was analyzed in Dover and Plant City based on final disease severity and AUDPC (Table 3). In both locations, the final disease severity and AUDPC were significantly lower for the rotational program (Table 3). Among the individual treatments, there was no significant difference between the performance of Merivon and Luna Experience in Dover whereas, in Plant City, Merivon performed statistically better than Luna Experience (Table 3). In Parrish, there was no significant variety-application timing interaction for Luna Experience and the rotational program $(P=0.4036$ and 0.6207 , respectively).

Table 3. Effect of fungicide programs on foliar disease severity, based on comparisons among seasonal programs that include an at bloom application with the nontreated control, in trials performed at pomegranate orchards in Dover, FL (variety Vietnam) and Plant City, FL (variety Angel Red)

\begin{tabular}{|c|c|c|c|c|}
\hline \multirow[b]{2}{*}{ Fungicide programs } & \multicolumn{2}{|c|}{ Doverw } & \multicolumn{2}{|c|}{ Plant City ${ }^{w}$} \\
\hline & AUDPC $^{\mathbf{x}}$ & $\% \mathrm{DS}_{\mathrm{f}}{ }^{\mathrm{y}}$ & AUDPC $^{\mathbf{x}}$ & $\% \mathrm{DS}_{\mathbf{f}}^{\mathrm{y}}$ \\
\hline Nontreated control & $2,290 \mathrm{a}$ & $39.5 \mathrm{a}$ & $4,025 \mathrm{a}$ & $62.5 \mathrm{a}$ \\
\hline Merivon & $1,356 \mathrm{~b}$ & $17.9 \mathrm{bc}$ & $2,187 \mathrm{~b}$ & $22.1 \mathrm{c}$ \\
\hline Luna Experience & $1,231 \mathrm{~b}$ & $19.1 \mathrm{~b}$ & $1,481 \mathrm{c}$ & $49.1 \mathrm{~b}$ \\
\hline Rotational program ${ }^{z}$ & $931 \mathrm{c}$ & $9.4 \mathrm{c}$ & $768 \mathrm{~d}$ & $9.4 \mathrm{~d}$ \\
\hline$P>F$ & $<0.0001$ & 0.0002 & $<0.0001$ & $<0.0001$ \\
\hline
\end{tabular}

${ }^{\mathrm{w}}$ Means followed by the same letter are not significantly different according to Fisher's least significant difference test $(\alpha=0.05)$.

$x$ Area under the disease progress curve (AUDPC) was calculated using the formula $\Sigma\left\{\left[\left(x_{i}+x_{i-1}\right) / 2\right]\left(t_{i}-t_{i-1}\right)\right\}$, where $x_{i}$ is the midpercentage of the Horsfall-Barratt rating at each evaluation time and $\left(t_{i}-t_{i-1}\right)$ is the time between evaluations; values represent least square (LS) means for each treatment.

y Values represent the LS mean of the percent final disease severity for each treatment.

${ }^{\mathrm{z}}$ Rotational fungicide program included one rotation at bloom and one seasonal rotation for each product rotated throughout the season: Merivon (22 March and 16 June), Luna Experience (7 April and 9 August), and Penncozeb 75DF (19 May and 12 July).
However, for Merivon, there was a significant variety-application timings interaction $(P=0.0009)$, thus application timings were analyzed separately for each pomegranate variety (data not shown).

Effect of fungicide application timing on foliar and fruit diseases. Effect of application timing on Luna Experience performance. Final disease severity on pomegranate trees treated with Luna Experience

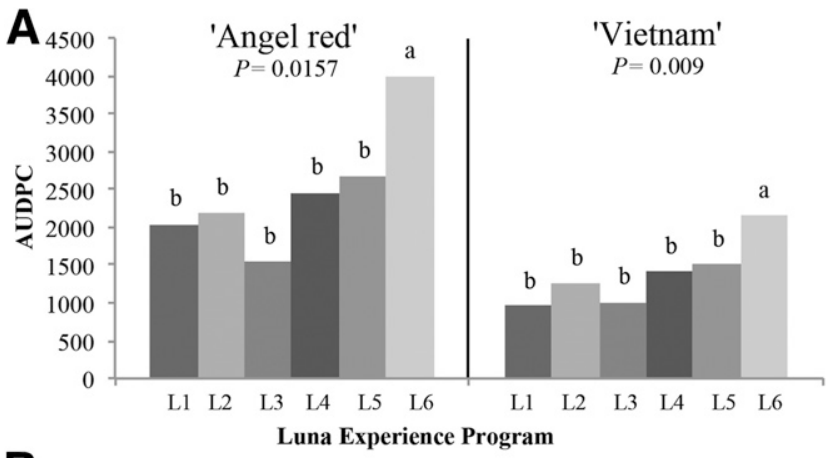

B

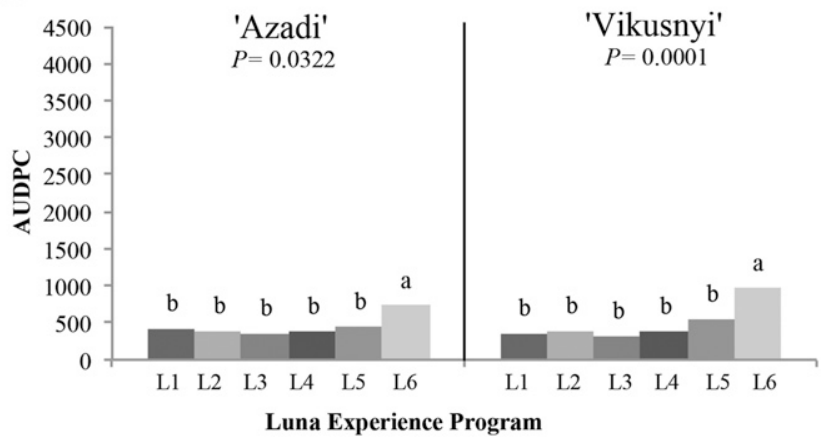

Fig. 1. Effect of Luna Experience on foliar disease severity, based on area under the disease progress curve (AUDPC), in field trials performed at pomegranate orchards in A, Dover (variety Vietnam), Plant City (variety Angel Red), and B, Parrish (varieties Azadi and Vikusnyi). AUDPC was calculated using the formula $\Sigma\left\{\left[\left(x_{i}+x_{i-1}\right) / 2\right]\left(t_{i}-\right.\right.$ $\left.\left.t_{i-1}\right)\right\}$, where $x_{i}$ is the midpercentage of the Horsfall-Barratt rating at each evaluation time and $\left(t_{i}-t_{i-1}\right)$ is the time between evaluations; values represent least square means for each treatment. For each pomegranate variety, bars with the same letter are not statistically different based on Fisher's protected least significant difference test $(\alpha=0.05)$. Applications of Luna Experience are abbreviated as $L 1=$ four seasonal, beginning at bloom; $\mathrm{L} 2=$ two at bloom and two postbloom; $\mathrm{L} 3=$ two at bloom; $L 4=$ one at bloom and two postbloom; $L 5=$ four postbloom; and $L 6=$ nontreated control.

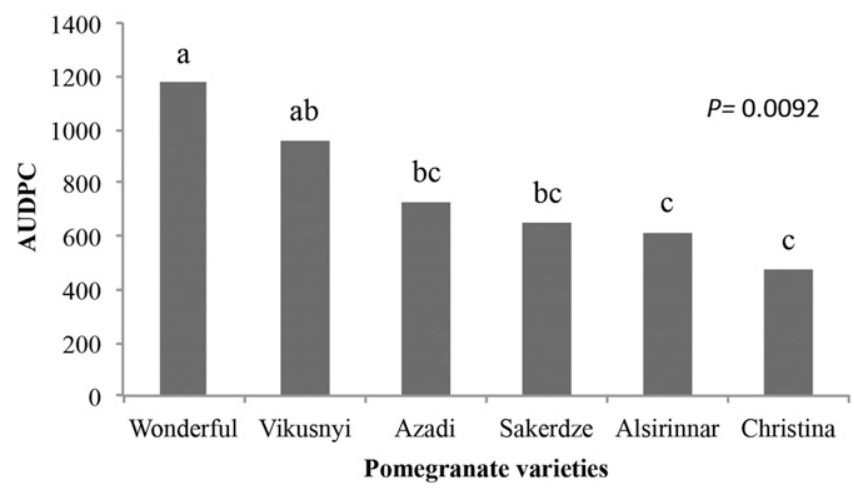

Fig. 2. Effect of pomegranate varieties (Wonderful, Vikusnyi, Azadi, Sakerdze, Alsirinnar, and Christina) on foliar disease severity at trials performed in Parrish. Gray bars represent area under the disease progress curve (AUDPC), which was calculated using the formula $\Sigma\left\{\left[\left(x_{i}+x_{i-1}\right) / 2\right]\left(t_{i}-t_{i-1}\right)\right\}$, where $x_{i}$ is the midpercentage of the Horsfall-Barratt rating at each evaluation time and $\left(t_{i}-t_{i-1}\right)$ is the time between evaluations; values represent least square means for the nontreated controls. Bars followed by the same letter are not statistically significant $(P=0.05)$ according to Fisher's protected least significant difference test. 
ranged from 45.8 to $54.2,12.2$ to 24.8 , and 6 to $7.5 \%$ at trial locations in Plant City, Dover, and Parrish, respectively (Supplementary Tables S1 to S3). Based on AUDPC, all Luna Experience treatments (L1 to L5) significantly reduced disease levels compared with the nontreated control (L6), regardless of application timing or plant variety at all three locations (Fig. 1). There was no significant differences among one (L1 and L4) or two (L2 and L3) at bloom applications and treatments applied only later (L5) in the season in Plant City and Dover (Fig. 1A). In Parrish, there were significant differences among the varieties used in this study based on the nontreated control $(P=0.0092 ;$ Fig. 2$)$. There was also a significant interaction of variety and application timing; thus, results based on AUDPC are shown for each variety (Figs. 1, 3, and 4). Based on AUDPC for Azadi, treatments that included at bloom applications of Luna Experience (L1 to L4) did not differ from the treatment consisting of only postbloom applications (L5) (Fig. 1B). On Vikusnyi, significant differences were observed among Luna Experience treatments and the nontreated control $(P=0.0001)$ (Fig. 1B). Based on AUDPC for Vikusnyi, four seasonal applications of Luna Experience initiated at bloom (L1) showed significantly lower disease than treatment L5 consisting of four postbloom applications. There were no significant differences among treatments $(P>0.05)(\mathrm{L} 2, \mathrm{~L} 3$, and L4) that included at least one at bloom application (Fig. 1B).

Based on the fruit rot incidence, in comparison with the nontreated control there were significant differences between timing of application in the beginning of the season for trees treated with Luna Experience in Plant City $(P=0.0060)$ and Dover $(P=0.0129)$ but not in Parrish $(P=0.3477)$ (Table 4$)$. However, by the end of the season,

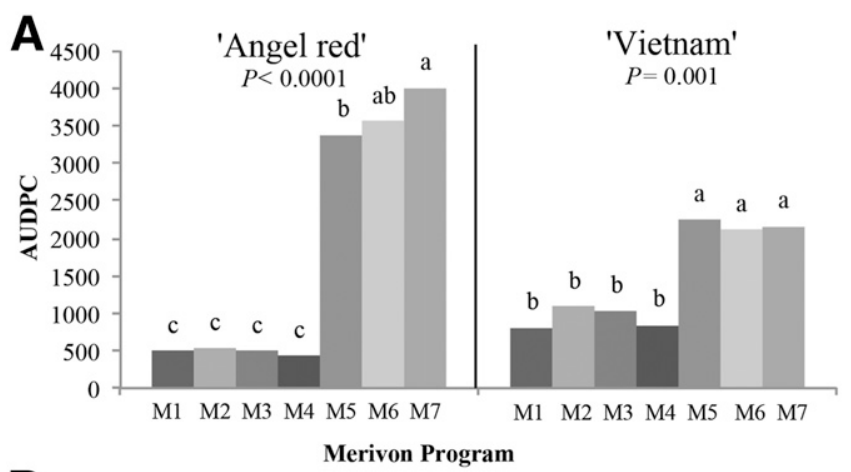

B

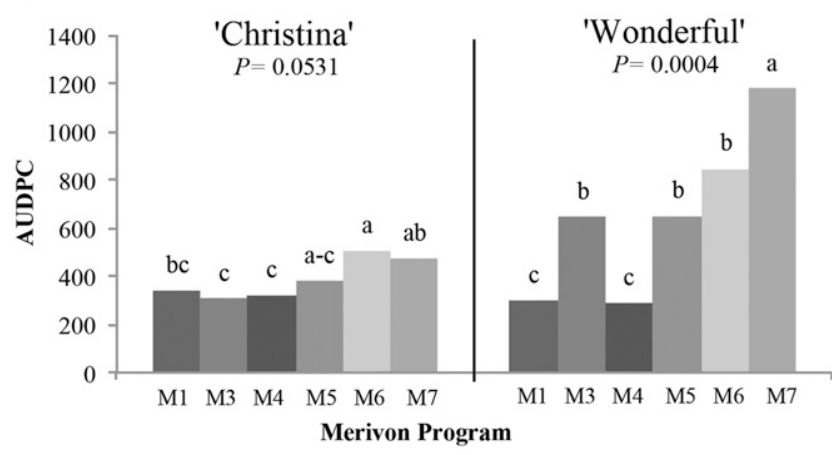

Fig. 3. Effect of Merivon on foliar disease severity, based on area under the disease progress curve (AUDPC), in field trials performed at pomegranate orchards in $\mathbf{A}$, Dover (variety Vietnam) and Plant City (variety Angel Red) and B, Parrish (varieties Christina and Wonderful). AUDPC was calculated using the formula $\Sigma\left\{\left(\left(x_{i}+x_{i-1}\right)\right]\right.$ 2] $\left.\left(t_{i}-t_{i-1}\right)\right\}$, where $x_{i}$ is the midpercentage of the Horsfall-Barratt rating at each evaluation time and $\left(t_{i}-t_{i-1}\right)$ is the time between evaluations; values represent least square means for each treatment. For each pomegranate variety, bars with the same letter are not statistically different based on Fisher's protected least significant difference test $(\alpha=0.05)$. Applications of Merivon are abbreviated as $\mathrm{M} 1$ = four seasonal, beginning at bloom; M2 = two at bloom and two postbloom (only performed in Plant City and Dover); $\mathrm{M} 3=$ two at bloom, low rate; $\mathrm{M} 4=$ two at bloom, high rate; $\mathrm{M} 5=$ two postbloom, low rate; $\mathrm{M} 6$ = two postbloom, high rate; and M7 = nontreated control. fungicide treatment had no significant effect on fruit rot incidence at any of the locations. Two at bloom applications of Luna Experience (L3) reduced disease by 66.6 and $66.8 \%$ in Plant City and Dover, respectively, in comparison with the nontreated control (Table 4). Luna Experience only reduced fruit rot in treatments that included at bloom applications in Plant City, relative to the nontreated control. Regardless of timing, Luna Experience applications had no significant effect on marketable fruit yields in Plant City or Parrish (data not shown).

Effect of application timing on Merivon performance. Pomegranate trees treated with Merivon showed disease severity ranging from 4.5 to $62.5,12.2$ to 28 , and 6 to $37.5 \%$, in Plant City, Dover, and Parrish, respectively, based on the final evaluation (Supplementary Tables S1 to S3). Furthermore, based on AUDPC, all Merivon treatments resulted in an average disease control of 89.2, 62.5, and $75.6 \%$ compared with the nontreated control in Plant City, Dover, and Parrish, respectively (Fig. 3). Merivon treatments that included at least one at bloom application (M1, M2, M3, and M4) provided higher levels of disease control than treatments consisting of only postbloom (M5 and M6) applications in Plant City $(P<0.0001)$ and Dover $(P=0.001)$ (Fig. 3A). In Parrish, differences of marginal significance $(P=0.0531)$ were observed among Merivon application treatments on Christina, with two at bloom applications (M3 and M4) resulting in the highest level of disease control (Fig. 3B). Results on Wonderful showed that seasonal Merivon applications initiated at bloom (M3) at a low rate $(83.8 \mathrm{ml} / \mathrm{ha})$ or at bloom applications (M4) at the high rate $(167.5 \mathrm{ml} / \mathrm{ha})$ were the most effective treatments

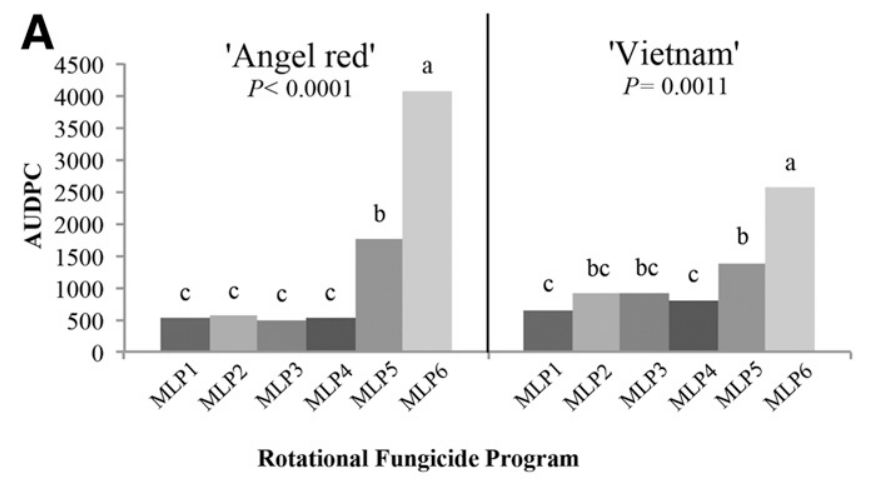

B

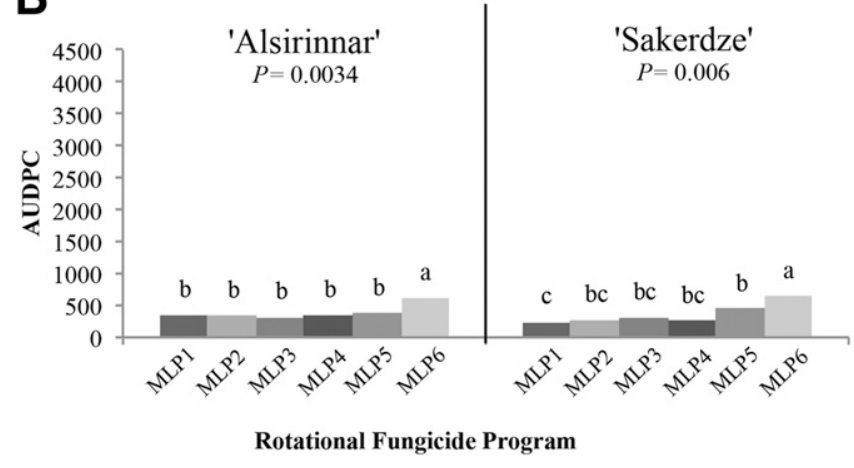

Fig. 4. Effect of rotational applications of Merivon, Luna Experience, and Penncozeb 75DF (MLP) on foliar disease severity, based on area under the disease progress curve (AUDPC), in field trials performed on pomegranate orchards in A, Dover (variety Vietnam) and Plant City (variety Angel Red), and B, Parrish, FL (varieties Alsirinnar and Sakerdze). AUDPC was calculated using the formula $\Sigma\left\{\left(x_{i}+x_{i-1}\right) /\right.$ 2] $\left.\left(t_{i}-t_{i-1}\right)\right\}$, where $x_{i}$ is the midpercentage of the Horsfall-Barratt rating at each evaluation time and $\left(t_{i}-t_{i-1}\right)$ is the time between evaluations; values represent least square means for each treatment. For each pomegranate variety, bars with the same letter are not statistically different based on Fisher's protected least significant difference test $(\alpha=0.05)$. Rotational applications are abbreviated as MLP1 $=$ one rotation at bloom and one postbloom, MLP2 $=$ one rotation at bloom and one postbloom, MLP3 $=$ two rotations at bloom, MLP4 $=$ one rotation at bloom at the beginning of the season and one postbloom at the end of season, MLP5 = two postbloom rotations, and MLP6 = nontreated control. 
$(P=0.0004)$, reducing AUDPC by $76 \%$ compared with the nontreated control (Fig. 3B).

Results from fruit rot incidence on pomegranate trees treated with Merivon showed significant differences depending on the application timing at the beginning of the season in Plant City $(P=$ $0.0023)$ and Parrish $(P=0.0292)$ but at the end of the season only in Parrish $(P=0.0082)$ (Table 4$)$. Four seasonal Merivon applications beginning at bloom (M1) resulted in $78 \%$ disease control by the end of the season in Parrish. Merivon application had no significant effect on marketable fruit yields in Plant City (data not shown) whereas, in Parrish, Merivon applications exhibited a significant effect on marketable fruit yields $(P=0.0003)$ (Table 4$)$, with all treatments that included at least one at bloom application (M1 to M4) exhibiting significantly higher yields in comparison with the nontreated control (M7) or treatments that only received postbloom Merivon applications (M5 and M6).

Effect of application timing on the performance of a fungicide rotation program. Pomegranate trees treated with a rotation of Merivon, Luna Experience, and Penncozeb showed an average disease severity ranging from 6 to $21.2,7.5$ to 15.3 , and 4.5 to $6 \%$, in Plant City, Dover, and Parrish, respectively, (Supplementary Tables S1 to S3). Based on AUDPC, the fungicide rotation program reduced disease by $87.5,74.2$, and $47.5 \%$ in comparison with the nontreated control in Plant City, Dover, and Parrish, respectively (Fig. 4). When the rotational program included at least one at bloom application (MLP1, MLP2, MLP3, and MLP4) it had a significant effect on the AUDPC in comparison with seasonal application (MLP5) in treatments that only consisted of postbloom fungicide applications in Plant City $(P<0.0001)$ and Dover $(P=0.0011)$ (Fig. 4A). In Parrish, all of the fungicide treatments applied on
Alsirinnar and Sakerdze significantly reduced AUDPC in comparison with the nontreated control $(P<0.0034)$ (Fig. 4B). However, the treatment MLP1 when applied on Sakerdze resulted in the highest disease control.

Based on the fruit rot incidence (Table 5), there were no significant differences between fungicide application treatments at the beginning or end of the season in Plant City $(P=0.1878$ and 0.3081 , respectively) and Dover $(P=0.5577$ and 0.6312 , respectively) whereas, in Parrish, there were significant differences between fungicide application treatments at the end of the season $(P=0.0004)$. Two treatments, MLP2 and MLP3, showed significantly lower fruit rot incidence compared with the nontreated control (Table 5). Fungicide applications had a significant effect on marketable fruit yield in Parrish $(P=0.0011)$ (Table 5).

\section{Discussion}

Our main goal was to develop effective fungicide programs to control foliar and fruit diseases of pomegranate. Currently, there are no systemic or contact chemical fungicides labeled for seasonal disease control on pomegranate in the United States The only conventional fungicide labeled is fludioxonil (Scholar), which can only be applied to control postharvest diseases of pomegranate (CDMS 2016). Thus, the management of pomegranate diseases across the southeastern United States has relied only on the use of biopesticides or on cultural practices such as orchard sanitation, including removal of crop debris from the orchard and pruning diseased plant parts and removing them from the site to prevent reinfection. In this study, we demonstrate the potential of three fungicides, applied separately and in a rotational program, to control foliar and fruit diseases of pomegranate at three separate locations in Florida.

Table 4. Effect of Luna Experience (Luna) and Merivon on the average incidence of diseased fruit per tree at the beginning and end of the season, and on average marketable fruit yield at the end of the season in pomegranate trials performed in Plant City, Dover, and Parrish, FL

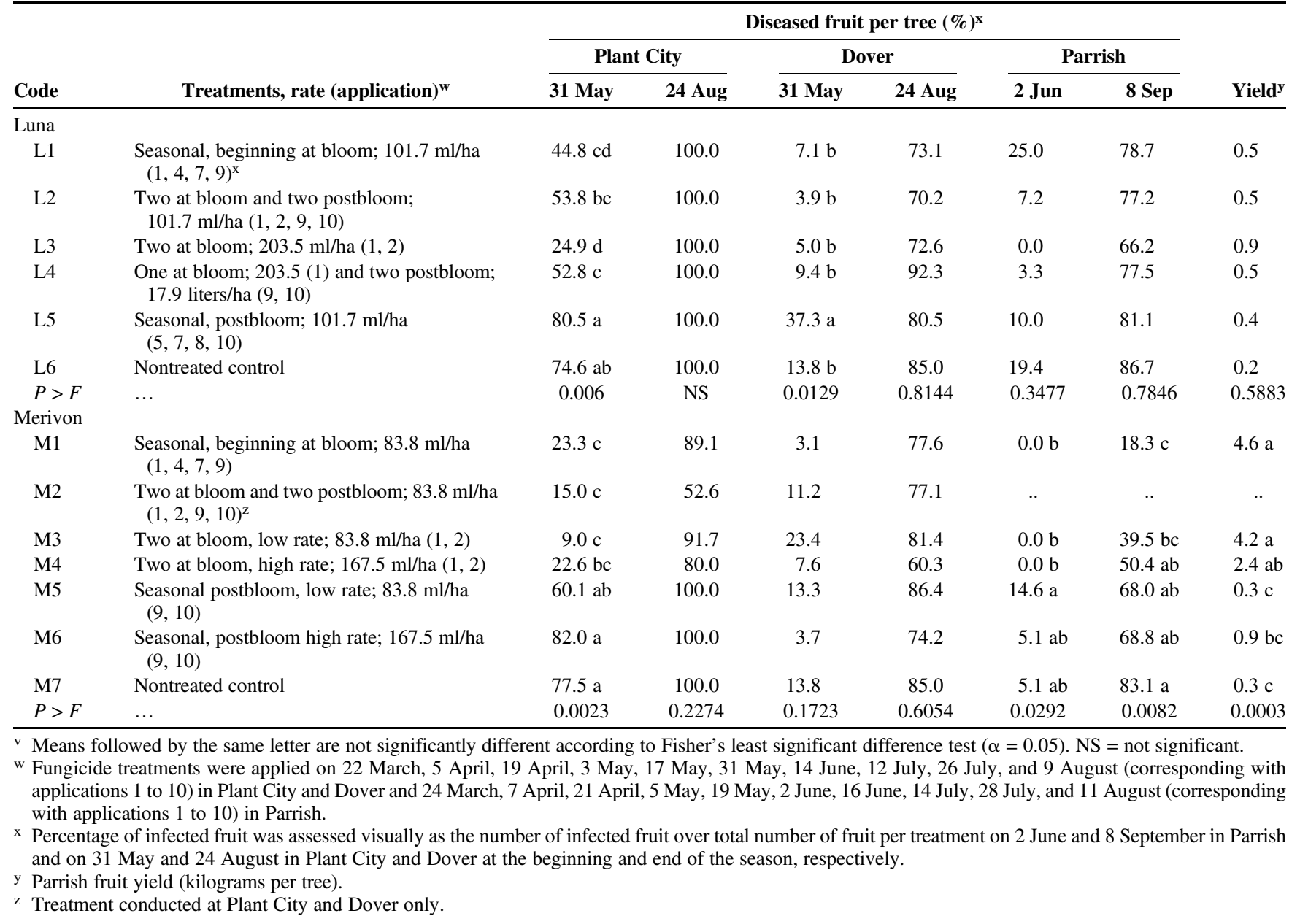


All tested fungicide programs effectively reduced leaf spot in comparison with the nontreated control at all three locations. However, the fungicide programs varied in effectiveness against fruit rot based on fungicide, variety, location, and time of evaluation. For example, Luna Experience effectively reduced fruit rot incidence in Plant City and Dover at the beginning of the season but not in Parrish. Merivon only reduced fruit rot incidence in Plant City at the beginning of the season but failed in Dover and Parrish. Similarly, the rotational program was only effective in reducing fruit infections in Parrish. These variable levels of performance could be a consequence of several factors, including differing levels of disease pressure, rainfall, tree age, plant varieties, and cultural practices at the different locations, as well as the combination of these different factors. Also, the varieties used in Plant City and Parrish are deciduous, while the variety Vietnam at Dover is an evergreen that continuously produces new leaves and flowers throughout the year. Thus, for orchards with an evergreen variety, there is a constant source of inoculum for disease dissemination as well as an inoculum carryover from season to season, and field sanitation becomes a real challenge for the grower. Our results also indicated that fungicide programs evaluated in this study were more successful on foliage than fruit, which is likely due to higher disease pressure from greater levels of rainfall later in the season, which not only favor fruit rot but also promote premature fruit drop. However, it is difficult to ascertain whether fruit disease is the primary cause of fruit losses at the end of the season or is secondary due to cracking or splitting of fruit or insect damage. All of the factors listed above should be considered in choosing the best management strategies to control pomegranate diseases across the southeastern United States. In the future, it will be important to determine the environmental factors required for disease development for the main pathogens infecting pomegranate, including Colletotrichum spp., D. punicae, and $N$. parvum.

At bloom fungicide applications are typically recommended for the control of fungal fruit rot pathogens that remain quiescent in the blooms of several crops (Arauz 2000; Peres et al. 2002; Thomas-Sharma and Scherm 2017). Thus, nonsymptomatic pomegranate flower buds were used for pathogen recovery and our results showed that several fungal species were already present. In fact, more than $80 \%$ of the flower buds analyzed were infected with at least one fungal species, which probably was a result of latent infections. Therefore, it is not surprising that our results with at bloom fungicide applications are similar to those reported for the control of citrus postbloom fruit drop caused by Colletotrichum spp. (Arauz 2000; Peres et al. 2002). Merivon was also compared at a high or low dosage, and our results demonstrated that leaf spot control was equivalent regardless of dosage.

In conclusion, all of the fungicide programs tested were shown to be effective in reducing foliar and fruit diseases of pomegranate in field trials performed across Florida. This work shows the importance of fungicide application timing on pomegranate disease management. Furthermore, at bloom fungicide applications are shown to be critical for effective disease management in pomegranate. Another strategy recommended for the management of pomegranate diseases is to use plant resistance (Munhuweyi et al. 2016). However,

Table 5. Effect of rotational applications of Merivon, Luna Experience, and Penncozeb 75DF (MLP) on the average incidence of diseased fruit per tree at the beginning and end of the season, and on average marketable fruit yield at the end of the season in pomegranate trials performed in Plant City, Dover, and Parrish, $\mathrm{FL}^{\mathrm{w}}$

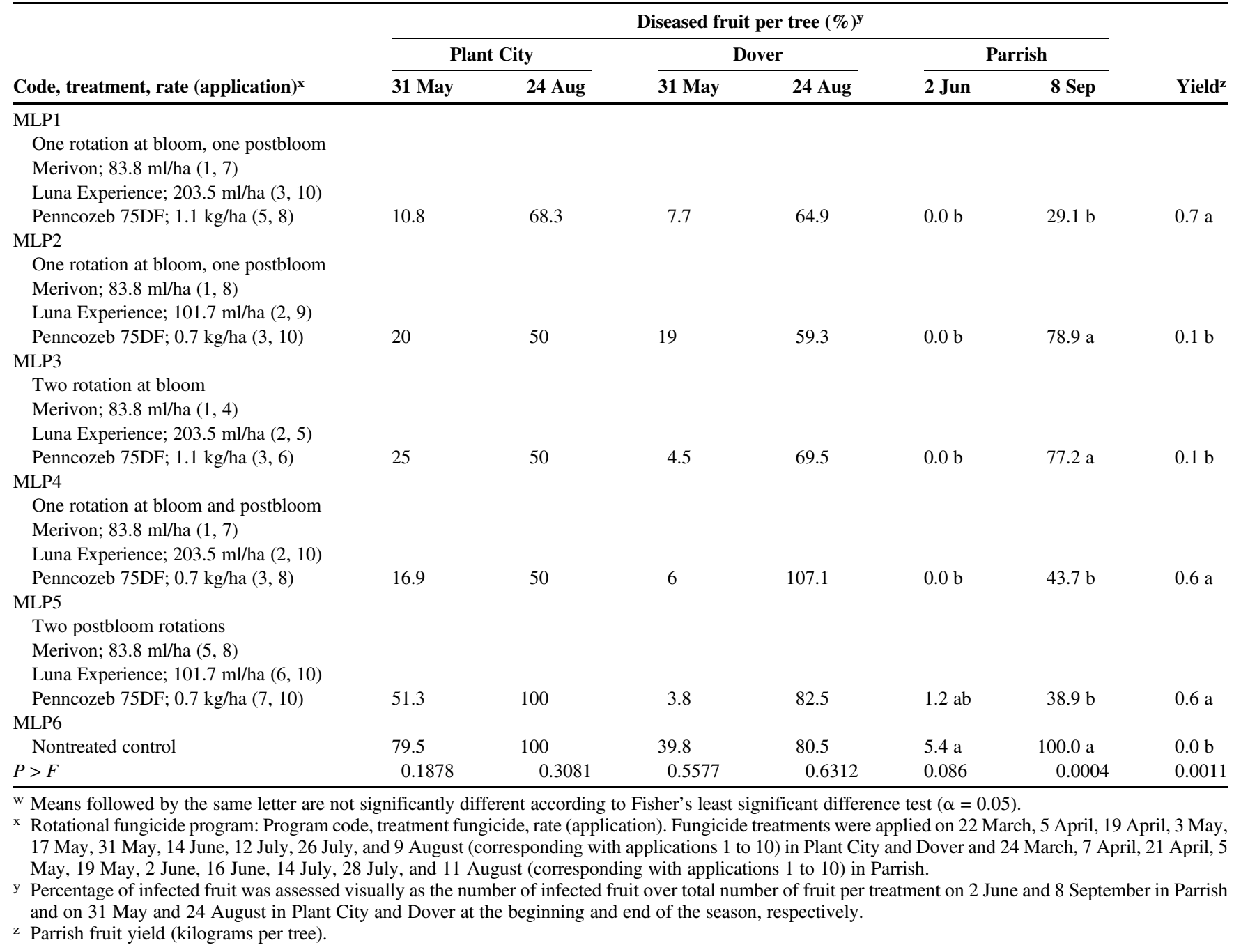


very few studies have been performed at the field level to assess the level of susceptibility of pomegranate varieties to diseases. This is the first time the susceptibility of Alsirinnar, Sakerdze, Azadi, Vikusnyi, Christina, and Wonderful grown under Florida environmental conditions has been reported. Our results indicated that Wonderful was the most susceptible variety, followed by Vikusnyi. However, the varieties Azadi, Sakerdze, Alsirinnar, and Christina exhibited some tolerance to leaf spot, which can be useful to breeding efforts.

Among six fungal isolates recovered from pomegranate flower buds in this study only two have been characterized (Colletotrichum spp. and D. punicae); thus, additional studies are needed to characterize and taxonomically classify Pestalotiopsis spp., Lasiodiplodia spp., and others. There is also a need to study potential differences in fungicide sensitivity among isolates from the various fungal species identified on flower buds such as the Colletotrichum spp. identified in Xavier et al. 2019b.

The fungicides tested in this study are not specifically labeled for pomegranate diseases in the United States, although efforts to pursue labeling are in progress. Thus, it is still critical that growers adopt cultural management strategies in order to reduce possible seasonal carryover of pathogens (Jadhav and Sharma 2009; Munhuweyi et al. 2016). Penncozeb 75DF is currently labeled on numerous crops, including pome and stone fruit, due to its broad-spectrum activity against several fungal pathogens (Gullino et al. 2010). However, due to its high efficacy, Penncozeb 75DF has been extensively used in the United States; thus, its registration on a new crop could be a challenge (Gullino et al. 2010). Testing of other contact fungicides besides Penncozeb 75DF could help in developing an alternative fungicide program for pomegranate growers. Fungicide resistance programs designed to prolong the effectiveness of systemic fungicides will be critical for the future of pomegranate production across the southeastern United States.

\section{Acknowledgments}

We thank S. Hughes, S. Kalb, and P. M. E. L. Lawson Hellu for technical assistance; Pacific Tomato Growers and Martha and Carl Sutherland for access to pomegranate orchards to conduct this study; and L. G. Cordova for valuable input on the statistical analysis.

\section{Literature Cited}

Arauz, L. F. 2000. Mango anthracnose: Economic impact and current options for integrated management. Plant Dis. 84:600-611.

Benagi, V., Ravi Kumar, M., Gowdar, S., and Pawar, B. B. 2011. Survey on diseases of pomegranate in Northern Karnataka, India. Acta Hortic. 890:509-511.

CDMS. 2016. Crop Data Management Systems, Inc. https://www.cdms.net

Chen, Y., Shao, D.-D., Zhang, A.-F., Yang, X., Zhou, M.-G., and Xu, Y.-L. 2014. First report of a fruit rot and twig blight on pomegranate Punica granatum caused by Pilidiella granati in Anhui Province of China. Plant Dis. 98:695.

Chung, K. R., Shilts, T., Ertürk, Ü., Timmer, L., and Ueng, P. P. 2003. Indole derivatives produced by the fungus Colletotrichum acutatum causing lime anthracnose and postbloom fruit drop of citrus. FEMS Microbiol. Lett. 226:23-30.

D'Aquino, S., Palma, A., Schirra, M., Continella, A., Tribulato, E., and La Malfa, S. 2010. Influence of film wrapping and fludioxonil application on quality of pomegranate fruit. Postharvest Biol. Technol. 55:121-128.

Ezra, D., Kirshner, B., Hershcovich, M., Shtienberg, D., and Kosto, I. 2015. Heart rot of pomegranate: Disease etiology and the events leading to development of symptoms. Plant Dis. 99:496-501.

Gullino, M. L., Tinivella, F., Garibaldi, A., Kemmitt, G. M., Bacci, L., and Sheppard, B. 2010. Mancozeb: Past, present, and future. Plant Dis. 94: 1076-1087.

Halbert, S. E., and Manjunath, K. L. 2004. Asian citrus psyllids Sternorrhyncha: Psyllidae and greening disease of citrus: A literature review and assessment of risk in Florida. Fla. Entomol. 87:330-353.

Hanlin, R. T. 1990. Illustrated Genera of Ascomycetes, Vol. I. American Phytopathological Society, St. Paul, MN, U.S.A.

Hanlin, R. T. 1998. Illustrated Genera of Ascomycetes, Vol. II. American Phytopathological Society, St. Paul, MN, U.S.A.

Hebert, T., and Clayton, C. 1963. Pomegranate fruit rot caused by Coniella granati. Plant Dis. Rep. 47:222-223.

Horsfall, J., and Barratt, R. 1945. An improved grading system for measuring plant disease. (Abstr.) Phytopathology 35:655.
Jadhav, V., and Sharma, K. 2009. Integrated management of diseases in pomegranate. In: Souvenir Abstr. 2nd Int. Symp. Pomegranate Minor Mediterr. Fruits. UAS Dharwad.

Jain, K., and Desai, N. 2018. Pomegranate the cash crop of India: A comprehensive review on agricultural practices and diseases. Int. J. Health Sci. Res. 8:315-336.

Jeffries, P., Dodd, J., Jeger, M., and Plumbley, R. A. 1990. The biology and control of Colletotrichum species on tropical fruit crops. Plant Pathol. 39: 343-366.

Johanningsmeier, S. D., and Harris, G. K. 2011. Pomegranate as a functional food and nutraceutical source. Annu. Rev. Food Sci. Technol. 2:181-201.

KC, A. N., and Vallad, G. E. 2015. Pomegranate (Punica granatum L.) in Florida: A disease snapshot. (Abstr.) Phytopathology 105:S2.6.

KC, A. N., and Vallad, G. E. 2016a. First report of Neofusicoccum parvum causing shoot blight and stem cankers on pomegranate in Florida. Plant Dis. 100:1783.

KC, A. N., and Vallad, G. E. 2016b. First report of Pilidiella granati causing fruit rot and leaf spots on pomegranate in Florida. Plant Dis. 100:1238.

Luo, Y., Hou, L., Förster, H., Pryor, B., and Adaskaveg, J. E. 2017. Identification of Alternaria species causing heart rot of pomegranates in California. Plant Dis. 101:421-427.

MacKenzie, S., Seijo, T., Legard, D., Timmer, L., and Peres, N. 2007. Selection for pathogenicity to strawberry in populations of Colletotrichum gloeosporioides from native plants. Phytopathology 97:1130-1140.

Mayfield, A. E., Peña, J. E., Crane, J. H., Smith, J. A., Branch, C. L., Ottoson, E. D., and Hughes, M. 2008. Ability of the redbay ambrosia beetle (Coleoptera: Curculionidae: Scolytinae) to bore into young avocado (Lauraceae) plants and transmit the laurel wilt pathogen (Raffaelea sp.). Fla. Entomol. 91: 485-487.

Michailides, T. J., and Morgan, D. P. 2016. Association of Botryosphaeria panicle and shoot blight of pistachio with injuries of fruit caused by Hemiptera insects and birds. Plant Dis. 100:1405-1413.

Morgan, D. P., and Michailides, T. J. 2012. Neofusicoccum mediterraneum causing cankers and Diplodia mutila and Diplodia seriata isolated from pomegranate (Punica granatum) in California. (Abstr.) Phytopathology 102:83.

Munhuweyi, K., Lennox, C. L., Meitz-Hopkins, J. C., Caleb, O. J., and Opara, U. L. 2016. Major diseases of pomegranate Punica granatum L., their causes and management-A review. Sci. Hortic. (Amsterdam) 211:126-139.

Nargund, V., Jayalakshmi, K., Benagi, V., Byadgi, A., Patil, R., Melgarejo, P., and Valero, D. 2012. Status and management of anthracnose of pomegranate in Karnataka State of India. Options Méditerr. Sér. A: Sémin. Méditerr. 103 117-120.

NASS. 2012. Census of Agriculture. United States Department of Agriculture-National Agricultural Statistics Service, Washington, DC, U.S.A.

Palavouzis, S., Tzamos, S., Paplomatas, E., and Thomidis, T. 2015. First report of Neofusicoccum parvum causing shoot blight of pomegranate in Northern Greece. New Dis. Rep. 32:10.

Palou, L., Taberner, V., Guardado, A., Del Río, M. Á., and Montesinos-Herrero, C. 2013. Incidence and etiology of postharvest fungal diseases of pomegranate Punica granatum cv. Mollar de Elche in Spain. Phytopathol. Mediterr. 52:478-489.

Patel, D. 2009. Chemical management of fruit spot of pomegranate caused by Colletotrichum gloeosporioides Penz. and Sacc. Indian Phytopathol. 62: 252-253.

Peres, N., MacKenzie, S., Peever, T., and Timmer, L. 2008. Postbloom fruit drop of citrus and key lime anthracnose are caused by distinct phylogenetic lineages of Colletotrichum acutatum. Phytopathology 98:345-352.

Peres, N., Souza, N., Zitko, S., and Timmer, L. 2002. Activity of benomyl for control of postbloom fruit drop of citrus caused by Colletotrichum acutatum. Plant Dis. 86:620-624.

Philip, S. 1979. Aspergillus rot of pomegranate fruits. Indian Phytopathol. 32:332.

Polashock, J. J., Ehlenfeldt, M. K., Stretch, A. W., and Kramer, M. 2005. Anthracnose fruit rot resistance in blueberry cultivars. Plant Dis. 89:33-38.

Prashanth, A., Sataraddi, A. R., Naik, M., Patil, M., and Patil, R. S. 2008 Evaluation of fungicides, bioagents and botanicals against pomegranate anthracnose. Indian J. Plant Prot. 36:283-287.

Quiroz, I. 2009. Granado perspectiva y oportunidades de un negocio emergente: Antecedentes de mercado. Fundación Chile, Santiago, Chile.

Sergeeva, V., Nair, N., and Spooner-Hart, R. 2008. Evidence of early flower infection in olives Olea europaea by Colletotrichum acutatum and C. gloeosporioides causing anthracnose disease. Australas. Plant Dis. Notes 3:81-82.

Sharma, R., and Tegta, R. 2011. Incidence of dry rot of pomegranate in Himachal Pradesh and its management. Acta Hortic. 890:491-499.

Spreen, T. H., and Baldwin, J. P. 2013. The impact of huanglongbing (HLB) on citrus tree planting in Florida. In: South. Agric. Econ. Assoc. (SAEA) 2013 Annu. Meet. Orlando, FL, U.S.A. doi:10.22004/ag.econ.142706

Tedford, E. C., Adaskaveg, J. E., and Ott, A. J. 2005. Impact of Scholar a new postharvest fungicide on the California pomegranate industry. Plant Health Prog. 10:94

Thomas-Sharma, S., and Scherm, H. 2017. Pre-and post-anthesis activity of fenbuconazole and triforine against blueberry flower infection by Monilinia vaccinii-corymbosi. Crop Prot. 96:180-187.

Thomidis, T. 2014. Fruit rots of pomegranate cv. Wonderful in Greece. Australas. Plant Pathol. 43:583-588. 
Úrbez-Torres, J., Hand, F. P., Trouillas, F., and Gubler, W. 2016. Pomegranate dieback caused by Lasiodiplodia gilanensis in California. Eur. J. Plant Pathol. 148:223-228.

Verma, N., MacDonald, L., and Punja, Z. 2006. Inoculum prevalence, host infection and biological control of Colletotrichum acutatum: Causal agent of blueberry anthracnose in British Columbia. Plant Pathol. 55: 442-450.

Wharton, P. S., and Diéguez Uribeondo, J. 2004. The biology of Colletotrichum acutatum. An. Jardin Bot. Madrid C.S.I.C. 61:3-22.

White, T. J., Bruns, T., Lee, S., and Taylor, J. 1990. Amplification and direct sequencing of fungal ribosomal RNA genes for phylogenetics. Pages
315-322 in: PCR Protocols: A Guide to Methods and Applications. M. A Innis, D. H. Gelfand, J. J. Sninsky, and T. J. White, eds. Academic Press, Elsevier Inc., San Diego, CA, U.S.A.

Xavier, K., KC, A. N., Crous, P., Groenewald, J. Z., and Vallad, G. 2019a. Dwiroopa punicae sp. nov. Dwiroopaceae fam. nov., Diaporthales, associated with leaf spot and fruit rot of pomegranate Punica granatum. Fungal Syst. Evol. 4:33-41.

Xavier, K., KC, A. N., Peres, N. A., Deng, Z., Castle, W. S., Lovett, W., and Vallad, G. E. 2019b. Characterization of Colletotrichum species causing anthracnose of pomegranate in the southeastern US. Plant Dis. 103: 2771-2780. 